\title{
Clotting activity of camel milk using crude extracts of ginger (Zingiber officinale) rhizome
}

\author{
Yonas Hailu ${ }^{1}$, Eyassu Seifu ${ }^{2^{*}}$ and Zelalem Yilma ${ }^{3}$ \\ ${ }^{1}$ School of Animal and Range Sciences, Haramaya UniversityP.O.Box138, Dire Dawa, Ethiopia. \\ ${ }^{* 2}$ Department of Food Science and Technology, Botswana College of Agriculture, Private Bag 0027, Gaborone, \\ Botswana.Tel: +267-365 0147. \\ ${ }^{3}$ Netherlands Development Organization (SNV), EDGET/EADD-ET Project, Country Project Mobilization Coordinator, \\ Churchill Road, Tracon Building, $6^{\text {th }}$ Floor, P.O. Box P.O. Box 40675, Addis Ababa, Ethiopia. \\ ${ }^{*}$ Corresponding Author Email: eyassu_seifu@yahoo.com
}

Abstract

\begin{abstract}
This study was conducted to assess the clotting activity of camel milk using ginger rhizome (Zingiber officinale) crude extracts (GCE) and identify the optimum $\mathrm{pH}$, temperature and concentration of GCE that would result in strong coagulation of camel milk. The result revealed that temperature, $\mathrm{pH}$ and concentration of GCE had significant $(P<0.05)$ effect on the clotting activity of camel milk. The highest camel MCA was observed at $\mathrm{pH}$ of 5.0 , temperature of $65^{\circ} \mathrm{C}$ and crude extract concentration of $10 \%$ by volume of milk, while the lowest value was recorded at $\mathrm{pH}$ of 4.5 , temperature $55^{\circ} \mathrm{C}$ and GCE concentration of $40 \%$ by volume of camel milk. Cow milk was considered for comparison of MCA and had the highest clotting activity at $\mathrm{pH}$ of 5.5 , temperature of $60^{\circ} \mathrm{C}$ and GCE concentration of $10 \%$ by volume of milk. An increase in camel MCA was observed with a decrease in milk pH from 5.5 to 5.0; however, camel MCA decreased when milk pH reduced to 4.5. Camel MCA increased with increasing temperature; however, it decreased with increase in GCE concentration. Hence, GCE can be used to coagulate camel by adjusting the temperature and $\mathrm{pH}$ of the milk.
\end{abstract}

Keywords: Camel milk, coagulation, clotting activity and ginger crude extract.

\section{INTRODUCTION}

Dromedary camels (Camelus dromedarius) produce more milk of high nutritional quality for a longer period of time in hostile environments(Khan and lqbal, 2001). Camel milk is consumed fresh in traditional pastoral systems in several countries. However, processing of camel milk into more shelf stable value added milk products is not yet well developed thus camel milk products are not common place (Farah and Bachmann, 1987; Mehaia, 2006). Unlike milk of cow and small ruminants, camel milk doesn't readily coagulate by rennet due to its inherent properties. However, possibilities of cheese-making from camel milk was reported (Khan et al., 2004; Mehaia, 2006; Ahmed and ElZubeir, 2011) using coagulants of animal origin.

In Ethiopia, although cheese-making from cow milk and consumption have been part of the culture of a substantial proportion of the society, cheese is not traditionally made from camel milk. Recently, camel chymosin was developed using recombinant DNA technology by Danish scientists (Kappeler et al., 2006). However, it is not easily available; when available it is not affordable particularly by pastoralists. Different scholars also indicated that availability of calf rennet for cheesemaking is curtailed by factors such as high cost and limited availability of coagulants (Jacob et al.,2010; Hashim et al.,2011a).

Globally, demand for milk coagulating enzymes started to exceed the supply since over 50 years and in 2009 only $20-30 \%$ of the demand could be met by calf rennet (Jacob et al., 2010). Searching for substituting coagulants from easily and locally available resources such as plant extracts is, thus, not only feasible but also essential in order to meet the demand for milk coagulants for manufacturing of processed camel milk products mainly cheese by pastoralists. Several researchers tested the coagulation potential of bovine milk using different plant extracts (Abdallaet al., 2011; Garcia et al., 2011; Hashim et al.,2011a).Crude extracts of ginger was 
used to coagulate cow milk (Llorente et al., 1997). The specific property of proteases in ginger rhizome extract that coagulates casein micelles makes it an appropriate and potential candidate that can be used for clotting camel milk. Ginger extract had higher proteolysis activity (Huang et al., 2011; Hashimet al., 2011a;Hashim et al., 2011b). Ginger extracted enzyme had high specificity for $\alpha$-casein followed by $\beta$-casein and $\mathrm{k}$-casein and exhibited a similar affinity for $k$-casein, $\alpha$ - and $\beta$ casein Hashim et al.(2011a) and higher specificity for K-casein with increasing temperature (Huang et al.,2011). As indicated by Hashim et al. (2011a), the clotting activity of ginger extract is higher than that of calf rennet and papain for cow milk; however, it is lower than mucor rennet.

In Ethiopia, there is very limited work conducted that targeted to improve the utilization of camel milk commonly produced by pastoralists. The current study was, therefore, conducted to assess the clotting activity of camel milk using ginger crude extract and identify the optimum $\mathrm{pH}$, temperature and concentration of the crude extract of ginger rhizome that results in strong coagulation of camel milk.

\section{MATERIALS AND METHODS}

Milk samples were obtained from pastorally managed camels from Erer valley of Eastern Ethiopia and transported in an icebox to the dairy technology laboratory of Haramaya University.For comparison, cow milk produced at Haramaya University dairy farm was used. Five litre of milk was sampled at a time from two pastoralist household and from two lactating cow. The milk was collected by directly milking into sterile bottles. The $\mathrm{pH}$ of milk samples was adjusted to $4.5,5.0$ and 5.5 as described by Farah and Bachman (1987). Temperature was adjusted to $55^{\circ} \mathrm{C}, 60^{\circ} \mathrm{C}$ and $65^{\circ} \mathrm{C}$ using a thermostatically controlled water bath (Model 25, Shaking Water Bath, Illinois-60647, Chicago) and a thermometer was used to check the temperature. The extraction of ginger crude extract was performed according to the procedure described by Hashim et al.(2011a) with some modification as follows. Briefly, fresh ginger rhizomes were peeled, chopped, washed with de-ionized water and frozen at $-23^{\circ} \mathrm{C}$, then homogenized using a blender (Model 38BL40 Blender 8010E,Christiano Scientific Equipment, USA) with five parts of cold acetone $(\mathrm{w} / \mathrm{v})\left(-23^{\circ} \mathrm{C}\right)$ and kept at $4^{\circ} \mathrm{C}$ for about 15-20 min. The homogenate was filtered through cotton cloth and the precipitate was further washed with cold acetone followed by air drying. The air dried material was made into powder using a food grinding mill (Model M20, KIKA ${ }^{\circledR}$ WERKW, Germany). The powder was then homogenized in $20 \mathrm{mM}$ phosphate buffer (pH 7.0) for 2.4 minutes (Hashim et al., 2011b) and the extract was filtered using a muslin cloth. The filtrate was centrifuged at $12,000 \mathrm{~g}$ for $20 \mathrm{~min}$ (Model 1020, D Centrifuge,
Centrurion Scientific LTD) and the supernatant was considered as crude extract.The milk containing $0.15 \mathrm{~g}$ of $\mathrm{CaCl}_{2}$ per litre of milk was prepared as suggested by FAO (2001). The milk clotting activity (MCA) was determined according to the method described by Soledad et al.(2007). Briefly, 10, 20, 30 and $40 \%$ by volume of the crude extract was added into $10 \mathrm{ml}$ of the milk samples and MCA was determined by rotating the test tube at regular intervals and checking for visible clot (fine curd) formation on the wall of the test tubes. The formula suggested by Guiama et al.(2010a) was used to calculate the MCA expressed in $\mathrm{U} / \mathrm{ml}$.

\section{$\operatorname{MCA}(\mathrm{U} / \mathrm{ml})=(100 / C T) \times \mathrm{S} / \mathrm{E}:$}

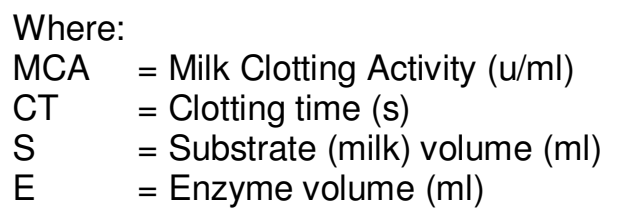

The result was expressed as $\mathrm{MCU} / \mathrm{ml}$. Only $10 \%$ (by volume) inclusion of GCE was considered for the curd firmness study with camel chymosin being used as control. Firmness of the curd samples was measured using Texture Analyzer (Model TA-Plus Lloyd, UK) according to Salvador and Fiszman (2004). Each experiment was executed in triplicate.Completely Randomized Design (CRD) with $3^{*} 3^{*} 4$ (three levels of temperature and $\mathrm{pH}$, and four levels of GCE concentration) factorial arrangement was used to analyze the MCA data. MCA treatment means were compared using Duncan's Multiple Range Test, while means of curd firmness were separated using Least Significant Difference method.

\section{RESULTS}

\section{Milk Clotting Activity}

The different levels of temperature, $\mathrm{pH}$ and concentration of crude extract of ginger rhizome used in the current study had marked $(P<0.05)$ difference on camel milk clotting activity (Table 1). The highest camel MCA $(\mathrm{MCU} / \mathrm{ml})$ was observed at a temperature of $65^{\circ} \mathrm{C}, \mathrm{pH}$ of 5.0 and crude extract concentration of $10 \%$ by volume with the lowest observed at temperature, $\mathrm{pH}$ and crude extract concentration of $55^{\circ} \mathrm{C}, 4.5$ and $40 \%$ by volume, respectively (Table 1 ). The crude extract of ginger had higher thermal stability showing its higher clotting units at higher temperature $\left(65^{\circ} \mathrm{C}\right)$ for camel milk (Table 1).

A significant difference $(P<0.05)$ was also observed in the clotting activity of cow milk among the different levels of temperature, $\mathrm{pH}$ and concentration of ginger crude extract (Table 2$)$. The clotting activity $(\mathrm{MCU} / \mathrm{ml})$ of cow milk was higher at a temperature of $60^{\circ} \mathrm{C}, \mathrm{pH}$ of 5.5 and crude extract concentration of $10 \%$ by volume (Table 2 ). 
Table 1. Clotting activity (MCU/ml) of camel milk using crude extracts of ginger.

\begin{tabular}{|c|c|c|c|c|c|c|c|c|c|}
\hline $\begin{array}{l}\text { Concentration } \\
\text { of crude extract (\% inclusion by volume) in } 10 \mathrm{ml} \text { of camel } \\
\text { milk }\end{array}$ & $\begin{array}{l}55\left({ }^{\circ} \mathrm{C}\right) \\
\mathrm{pH} \\
4.5\end{array}$ & 5.0 & 5.5 & $\begin{array}{l}60\left({ }^{\circ} \mathrm{C}\right) \\
\mathrm{pH} \\
4.5\end{array}$ & Tempe & rature $\left({ }^{\circ} \mathrm{C}\right)$ & $\begin{array}{l}65\left({ }^{\circ} \mathrm{C}\right) \\
\mathrm{pH} \\
4.5\end{array}$ & 5.0 & 5.5 \\
\hline $\begin{array}{l}10 \% \\
20 \% \\
30 \% \\
40 \%\end{array}$ & $\begin{array}{l}7.49^{\mathrm{wn}} \\
4.17^{\mathrm{w}} \\
2.85^{\mathrm{w}} \\
2.32^{\mathrm{w}}\end{array}$ & $\begin{array}{l}16.37^{\mathrm{mn}} \\
11.37^{\mathrm{pqrst}} \\
9.48^{\mathrm{stu}} \\
12.76^{\mathrm{opgrs}}\end{array}$ & $\begin{array}{l}24.87^{\text {gn }} \\
14.74^{\text {mnop }} \\
11.24^{\text {grst }} \\
10.94^{\text {grst }}\end{array}$ & $\begin{array}{l}21.94^{\mathrm{nI}} \\
15.09^{\mathrm{lm} \mathrm{np}} \\
12.09^{\mathrm{opqrst}} \\
10.14^{\mathrm{rstu}}\end{array}$ & $\begin{array}{l}34.51^{\mathrm{c}} \\
20.06^{\mathrm{Jk}} \\
16.96^{\mathrm{kIm}} \\
14.00^{\mathrm{mnopq}}\end{array}$ & $\begin{array}{l}30.68^{\mathrm{ae}} \\
18.09^{\mathrm{kl}} \\
13.38^{\mathrm{no} p r} \\
9.27^{\mathrm{tu}}\end{array}$ & $\begin{array}{l}45.05^{\mathrm{D}} \\
25.88^{\mathrm{gg}} \\
21.30^{\mathrm{Il}} \\
20.08^{\mathrm{Ik}}\end{array}$ & $\begin{array}{l}59.26^{\mathrm{a}} \\
33.43^{\mathrm{ae}} \\
28.92^{\mathrm{et}} \\
23.48^{\mathrm{gnt}}\end{array}$ & $\begin{array}{l}26.01^{\mathrm{g}} \\
17.68^{\mathrm{KI}} \\
13.53^{\mathrm{mnopqr}} \\
10.58^{\mathrm{qIstu}}\end{array}$ \\
\hline
\end{tabular}

Means with the same superscript letter in the table are not significantly different $(P>0.05)$. Values in the Table are means of three replications; Milk clotting activity was expressed as MCU/ml.

Table 2. Clotting activity (MCU/ml) of cow milk using crude extracts of ginger.

\begin{tabular}{|c|c|c|c|c|c|c|c|c|c|}
\hline \multirow{3}{*}{$\begin{array}{l}\text { Concentration of crude extract (\% inclusion by volume) in } 10 \mathrm{ml} \text { of } \\
\text { cow milk }\end{array}$} & \multicolumn{9}{|c|}{ Temperature $\left({ }^{\circ} \mathrm{C}\right)$} \\
\hline & $\begin{array}{l}55\left({ }^{\circ} \mathrm{C}\right) \\
\mathrm{pH}\end{array}$ & & & $\begin{array}{l}60\left({ }^{\circ} \mathrm{C}\right) \\
\mathrm{pH}\end{array}$ & & & $\begin{array}{l}65\left({ }^{\circ} \mathrm{C}\right) \\
\mathrm{pH}\end{array}$ & & \\
\hline & 4.5 & 5.0 & 5.5 & 4.5 & 5.0 & 5.5 & 4.5 & 5.0 & 5.5 \\
\hline $10 \%$ & $23.08^{\text {nop }}$ & $66.87^{\mathrm{de}}$ & $54.92^{\operatorname{tgh}}$ & $53.61^{\mathrm{ghl}}$ & $65.48^{\text {det }}$ & $150.79^{a}$ & $83.72^{C}$ & $98.15^{\mathrm{b}}$ & $103.70^{b}$ \\
\hline $20 \%$ & $13.43^{\mathrm{pqrs}}$ & $17.92^{\mathrm{opqr}}$ & $21.23^{\text {nopq }}$ & $21.77^{\text {nopq }}$ & $30.17^{\mathrm{Imn}}$ & $57.87^{\text {etgh }}$ & $56.02^{\text {etgh }}$ & $63.16^{\text {etg }}$ & $75.00^{\text {de }}$ \\
\hline $30 \%$ & $14.57^{\text {opqrs }}$ & $9.13^{\text {rs }}$ & $14.63^{\text {opqrs }}$ & $9.52^{\text {rs }}$ & $22.41^{\text {nop }}$ & $35.80^{\mathrm{klm}}$ & $56.61^{\text {etgh }}$ & $34.57^{\mathrm{klm}}$ & $50.93^{\text {hIJ }}$ \\
\hline $40 \%$ & $10.73^{\text {qrs }}$ & $4.81^{\mathrm{s}}$ & $10.80^{\text {qrs }}$ & $7.14^{\mathrm{rs}}$ & $15.97^{\text {opqrs }}$ & $42.46^{1 \mathrm{Jk}}$ & $54.17^{\operatorname{tgn}}$ & $25.04^{\mathrm{mno}}$ & $39.81^{\mathrm{kl}}$ \\
\hline
\end{tabular}

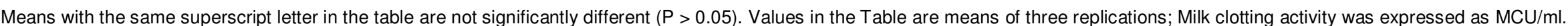

Generally, camel milk clotting activity increased with increasing temperature. However, an inverse relation was observed between the concentration of ginger crude extract and milk clotting activity, where milk clotting activity tended to decrease with increasing concentration of crude extract (Figure 1a). On the other hand, camel milk clotting activity increased up to $\mathrm{pH}$ of 5.0 then decreased at $\mathrm{pH}$ of 5.5 for all crude extract levels (Figure 1b).

\section{Curd firmness of camel milk}

An apparent difference $(P<0.05)$ in gel strength (load at yield) was observed between camel milk samples subjected to different combinations of temperature, $\mathrm{pH}$ and crude extract concentration levels (Table 3). The control treatment (milk treated with camel chymosin) had higher curd firmness compared with milk samples treated with ginger crude extracts (Table 3 ). Milk samples treated with ginger crude extract at $\mathrm{pH}$ of 5.0 temperature of $65^{\circ} \mathrm{C}$ and crude extract concentration of $0.1 \mathrm{ml} / \mathrm{ml}$ resulted in strong (firm) curd formation (Table 3 ). On the other hand, camel milk samples subjected to ginger crude extract at $\mathrm{pH}$ of 4.5 , temperature of $65^{\circ} \mathrm{C}$ and crude extract concentration of $10 \%$ by volume showed the weakest gel strength. Thus, treatment of camel milk with $10 \%$ (by volume) inclusion of ginger extract at $\mathrm{pH}$ value of 5.0 and temperature of $65^{\circ} \mathrm{C}$ can be used to coagulate camel milk and thus enable production of cheese from camel milk.

\section{Curd firmness of cow milk}

The gel strength of cow milk treated with crude extracts at different temperatures and $\mathrm{pH}$ of milk showed a significant difference $(P<0.05)$ (Table 4). Cow milk subjected to camel chymosin resulted in firm curd. This might be attributed to the specific property of kappa casein and milk coagulation potential of camel chymosin. Crude extract concentration of $10 \%$ by volume used at $\mathrm{pH}$ of 5.5 and temperature of $60^{\circ} \mathrm{C}$ resulted in higher curd firmness in com milk compared with curds formed by the other $\mathrm{pH}$ and temperature combinations (Table 4). Weak gel strength was recorded at $\mathrm{pH} 4.5$, temperature of $65^{\circ} \mathrm{C}$ and crude extract concentration of $10 \%$ by volume 
(A)

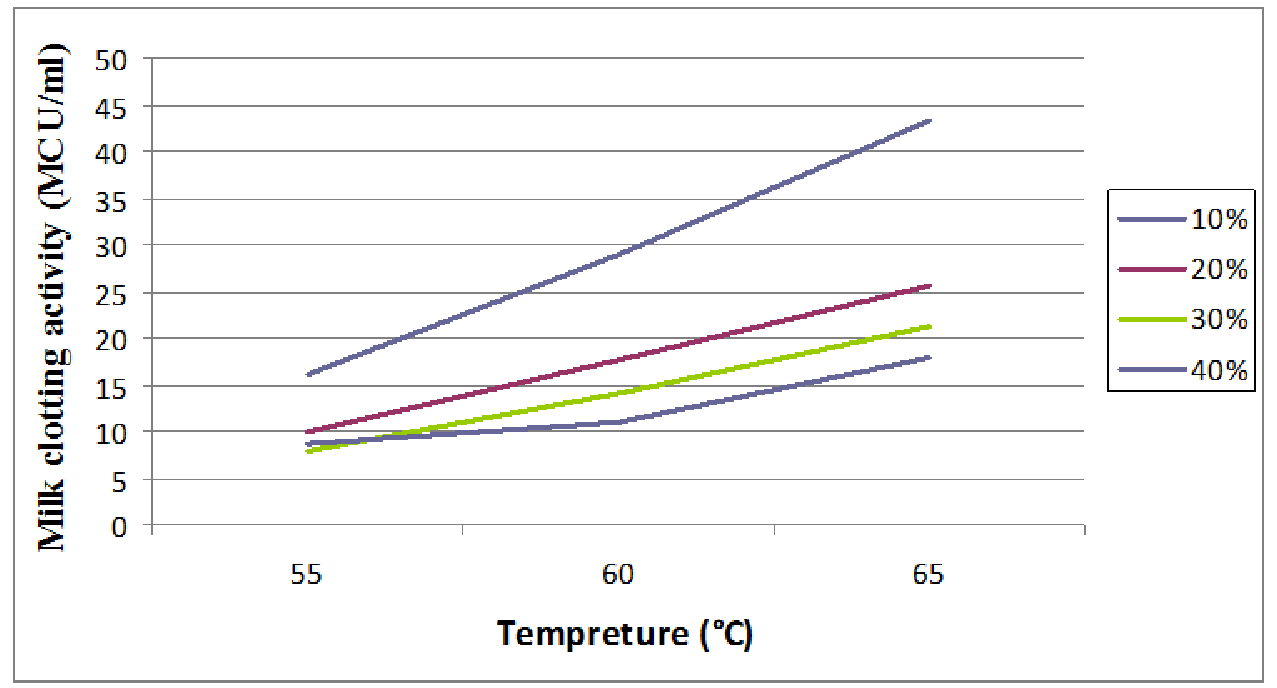

(B)

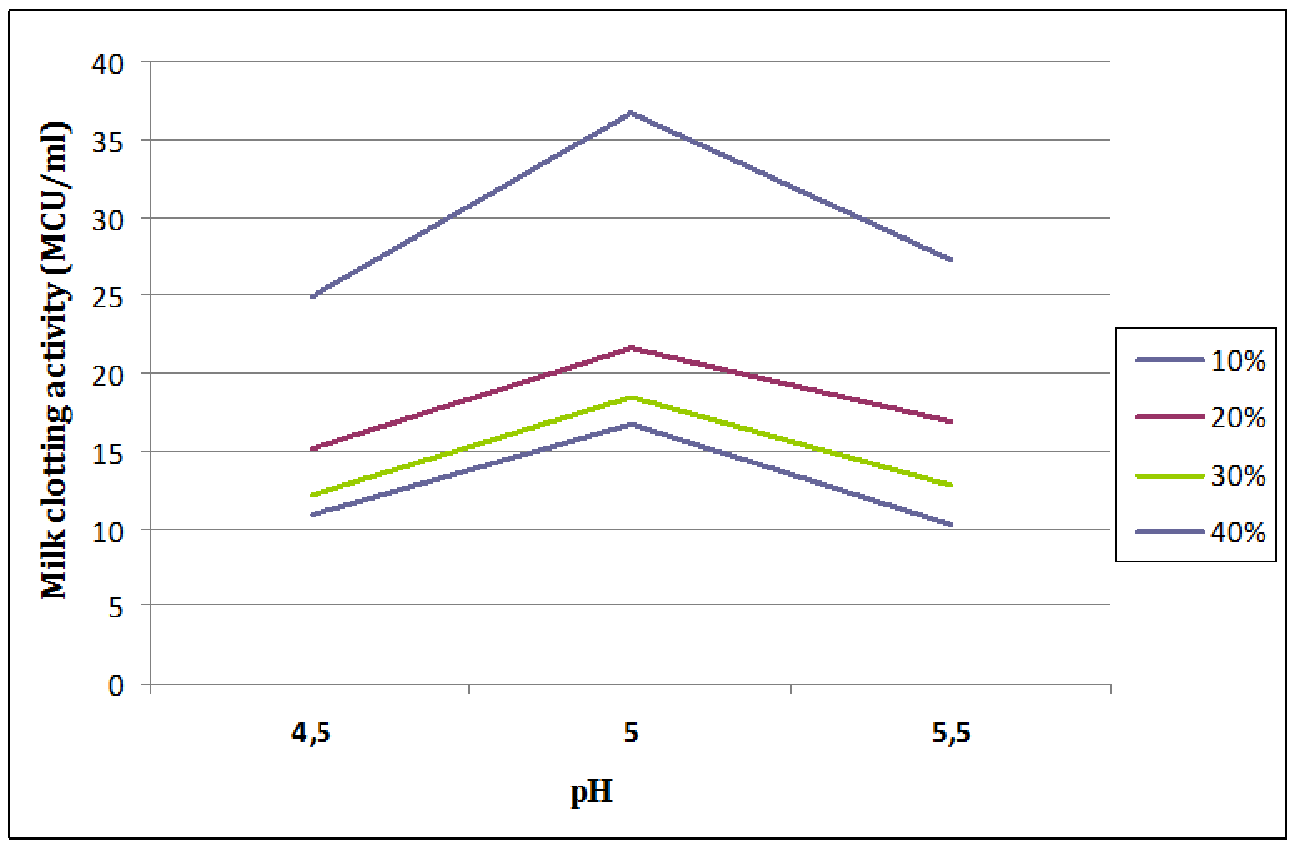

Figure 1. Clotting activity of camel milk ( $\mathrm{A}=$ Effect of temperature and crude extract concentration on clotting activity $(\mathrm{MCU} / \mathrm{ml}) ; \mathrm{B}=$ Effect of $\mathrm{pH}$ and crude extract concentration on milk clotting activity $(\mathrm{MCU} / \mathrm{ml})$ ).

\section{DISCUSSION}

The high clotting activity of camel milk observed in the current study might be attributed to the combined effect of the three parameters (temperature, $\mathrm{pH}$ and GCE concentrations); the active catalytic property of the crude extract, and the inherent characteristics of the substrate (milk). Earlier studies showed highest clotting activity of bovine milk by cysteine protease from ginger at high temperature $\left(60^{\circ} \mathrm{C}\right)$ and high $\mathrm{pH}(5.5)$ (Hashim et al., 2011a; Huang et al., 2011). In addition, Huang et al. (2011) indicated that ginger protease showed optimal proteolytic activity at temperature range of 40 to $60^{\circ} \mathrm{C}$ with maximum activity observed at $70^{\circ} \mathrm{C}$. They also reported that $70 \%$ of milk clotting activity was retained when the temperature was increased to $65^{\circ} \mathrm{C}$ and ginger protease exhibited higher specificity for $\mathrm{K}$ - casein with increase in temperature. Lowering the $\mathrm{pH}$ of dromedary milk delayed the solubilisation effect on casein micelles in which a transition state for solubilisation was observed at $\mathrm{pH}$ 5.0, and soluble casein amount in dromedary milk decreased at a pH below 5.0 (Kheroutou et al., 2003). Dromedary milk casein maintains its integrity till $\mathrm{pH}$ value of 5.5; however, below pH 5.0, caseins undergo 
94 Afr. J. Food Sci. Technol.

Table 3. Firmness of curd obtained by coagulation of camel milk with ginger crude extract and camel chymosin

\begin{tabular}{l|c}
\hline Treatments & Load at yield (Newton) \\
\hline T1 & $0.055416 \pm 0.003633^{\mathrm{D}}$ \\
\hline T2 & $0.037709 \pm 0.001759^{\mathrm{cc}}$ \\
\hline T3 & $0.044587 \pm 0.003169^{\mathrm{C}}$ \\
\hline T4 & $0.033901 \pm 0.002371^{\mathrm{d}}$ \\
\hline T5 & $0.087534 \pm 0.007502^{\mathrm{a}}$ \\
\hline
\end{tabular}

$\mathrm{T} 1=\left(\mathrm{pH} 5.5\right.$, temp $60^{\circ} \mathrm{C}$ and $10 \%$ by volume inclusion of ginger crude extract $), \mathrm{T} 2=\left(\mathrm{pH} 5.0\right.$, temp $65^{\circ} \mathrm{C}$ and $10 \%$ by volume inclusion of ginger crude extract), $\mathrm{T} 3=\left(\mathrm{pH} 5.5\right.$, temp $65^{\circ} \mathrm{C}$ and $10 \%$ by volume inclusion of ginger crude extract), $\mathrm{T} 4=\left(\mathrm{pH} 4.5\right.$, temp $65^{\circ} \mathrm{C}$ and $10 \%$ by volume inclusion of ginger crude extract $), \mathrm{T} 5=$ Control ( $\mathrm{pH} 6.3$, temp $36^{\circ} \mathrm{C}$ and $15 \%$ by volume inclusion of camel chymosin/litre of milk); Means with the same superscript letters within a column are not significantly different $(p>0.05)$; values in the Table are mean \pm SD of three replications.

Table 4. Firmness of curd obtained by coagulation of cow milk with ginger crude extract and camel chymosin.

\begin{tabular}{|l|r|}
\hline Treatment & Load at yield (Newton) \\
\hline T1 & $0.045035 \pm 0.001701^{\mathrm{D}}$ \\
\hline T2 & $0.036774 \pm 0.002478^{\mathrm{C}}$ \\
\hline T3 & $0.040498 \pm 0.005020^{\mathrm{DC}}$ \\
\hline T4 & $0.074687 \pm 0.001252^{\mathrm{a}}$ \\
\hline
\end{tabular}

$\mathrm{T} 1=\left(\mathrm{pH} 5\right.$, temp $65^{\circ} \mathrm{C}$ and $10 \%$ by volume inclusion of ginger crude extract $), \mathrm{T} 2=\left(\mathrm{pH} 4.5\right.$, temp $65^{\circ} \mathrm{C}$ and $10 \%$ by volume inclusion of ginger crude extract), $\mathrm{T} 3=\left(\mathrm{pH} 5\right.$, temp $60^{\circ} \mathrm{C}$ and $10 \%$ by volume inclusion of ginger crude extract), $\mathrm{T} 4=\mathrm{Control}\left(\mathrm{pH} 6.3\right.$, temp $36^{\circ} \mathrm{C}$ and $15 \%$ by volume of camel chymosin/litre of milk). Means with the same superscript letter within a column are not significantly different ( $p>0.05)$; Values in the table are mean $\pm S D$ of three replications.

extensive structural and biochemical modifications, and maximum solubilisation takes place at $\mathrm{pH}$ value of 4.9 (Attiaet al., 2000).

Coagulation activity strongly depends on the $\mathrm{pH}$ and temperature of milk (Soledad et al.,2007; Mohammed et al., 2010). Optimum proteolytic activity of Cynaracran dunculuson bovine casein occurred at $\mathrm{pH}$ range of 5.1 to 6.0 (Garcia et al.,2011). Llorenteet al. (1997) also indicated that crude extract of the upper (violet) part of mature flowers of Cynara scolymus $L$. exhibited optimum clotting activity at acid $\mathrm{pH}$ ranging from 3.5 to 5.0 for bovine milk and showed low thermal stability at temperatures above $45^{\circ} \mathrm{C}$. Protease from Cynara scolymus exhibited maximum activity at $70^{\circ} \mathrm{C}$ for clotting cow milk (Sidrachet al., 2005). Maximum MCA of crude and pure extracts of Jacaratia corumbensis for cow milk was also reported to occur at a temperature of $55^{\circ} \mathrm{C}$ for both extracts, while the optimum $\mathrm{pH}$ for crude and partially purified extracts was 6.5 and 7.0 , respectively (Rodrigues et al.,2009).

As indicated by Attia et al. (2000) and Kheroutouet al. (2003), gel strength of camel milk may have an effect on the solubilization point of camel milk casein. A special redistribution of dromedary milk casein was reported by Kheroutou et al. (2003) where permanent bonds were created between casein fractions at $\mathrm{pH} 5.0$ and a loose network was formed at low $\mathrm{pH}$ (4.4) that led to a pseudo curd formation. Attia et al. (2000) and Kheroutou et al. (2003), on the other hand, indicated that separated micelles start to gather together in globular or linear shape as the $\mathrm{pH}$ approaches to 5.5 and at $\mathrm{pH} 5.0$ and complete fusion and three dimensional networks are observed during acidification. Camel chymosin had threefold higher catalytic efficiency on camel $\mathrm{K}$-casein as compared to cow $\mathrm{K}$-casein (Kappeler et al., 2006).

Dilution of ginger crude extract had effect on milk clotting activity where MCA increased with decreasing crude extract concentration. Earlier reports indicated that bovine milk clotting time is affected by the type and protein content of the coagulant. Mehaia (1997), for instance, indicated that clotting time of bovine milk can be longer when concentration ratio of the protein content of the coagulant is increased as a result of increasing effective collision due to decreasing aqueous phase. Mariela et al. (2010) also reported that higher dilution of hieroymain fruit extract prolonged bovine milk clotting time. In the contrary, a significant decrease in bovine milk clotting time was observed with increasing the amount of Solanum macrocarpon extract (Guiama et al., 2010b).

\section{CONCLUSION}

Coagulation of camel milk could be achieved using ginger rhizome crude extract and improved firm curd could be obtained at a pH value of 5.0 , a temperature of $65^{\circ} \mathrm{C}$ and crude extract concentration of $10 \%$ by volume. Therefore, the coagulation of camel milk using ginger crude extract suggests the possibility of making cheese from camel milk using locally available coagulants. Further studies 
are needed to confirm the result by separating the pure milk clotting protease enzyme from ginger rhizome.

\section{ACKNOWLEDGEMENTS}

The authors are grateful to the Ministry of Education and Haramaya University for the study grant. The assistance of Dr. KefelegnKebede in data analysis and Tsige Tekelemariam, KebedeAsegaw, Haimanot Bizuneh, Shewangezaw Teketel, and Deribachewu Bekana in the laboratory work is highly appreciated.

\section{REFERENCES}

Abdalla MOM, Kheir SEO, El Owni OAO(2011). Effect of extraction method, ammonium sulphate concentration, temperature and $\mathrm{pH}$ on milk clotting activity of Solanumdubiumfruit extract. Advance J. Food Sci. Technol.3(1): 40-44.

Ahmed NAA, El Zubeir IEM (2011). Effect of salt level on some physical and chemical properties and acceptability of camel milk cheese. J.CamelidSci.4:40-48.

Attia H, Kherouatou N, Nasri M, Khorchani T (2000). Characterization of the dromedary milk casein micelle and study of its changes during acidification. Dairy Sci. Technol. 80 (5): 503-515

$\mathrm{FAO}(2001)$. The Technology of Making Cheese from Camel Milk (Camelusdromedarius).Animal Production and Health Paper, Vol. 113.Food and Agriculture Organization of the United Nations: Rome, Italy.

Farah Z, Bachmann MR (1987). Rennet coagulation properties of camel milk. Milchwissen.42(11): 689-692.

Garcia HS, Hernandez AL, Hill CG(2011). Enzyme technology- Dairy industry applications.Comprehensive Biotechnol.4: 567-574.

Guiama VD, Libouga DG, Ngah E,Mbofung CM (2010a). Milk clotting activity of berries extracts from nine Solanumplants. Afr. J. Biotechnol.9(25):3911-3918.

Guiama VD, Libouga DG, Ngah E, Beka RG, Ndi KC, Maloga B, Bindzi JM, Donn P,Mbofung CM(2010b). Milk clotting potential of fruit extracts from Solanumesculentum, SolanummacrocarponL. and Solanummelongena. Afr. J. Biotechnol.9(12): 1797-1802.

HashimaMM, Mingsheng D, Iqbal MF, Xiaohong C (2011a). Ginger rhizome as a potential source of milk coagulating cysteine protease. J.Phytochem. 72:458-464.

Hashim MM, lqbal MF, Xiaohong C, Mingsheng D (2011b). Impact of processing conditions on the milk clotting activity of crude protease extracted from Chinese ginger. International Conference on Food Engineering and BiotechnologyIPCBEE, Vol. 9. IACSIT Press, Singapore, pp. 327-331.

Huang XW, Chen LJ, Luo YB, Guo HY,Ren FZ (2011). Purification, characterization and milk coagulating properties of ginger proteases.J. Dairy Sci. 94: 2259-2269.
Jacob M, Jaros D, Rohm H (2011).Recent advances in milk clotting enzymes. Int.J.Dairy Technol.64:14-33.

Kappeler SR, Van den Brink HJM, Rahbek NH, Farah Z, Puhan Z, Hansen EB, Johansen $E(2006)$. Characterization of recombinant camel chymosin reveals superior properties for the coagulation of bovine and camel milk. J. Biochem.Biophys. Res.Commun. 342: 647-654.

Khan BB,lqbal A (2001). Production and composition of camel milk: Review.Pakistan J. Agric. Sci. 38: 3-4.

Khan $\mathrm{H}$, Athar $\mathrm{IH}$, Aslam M (2004). Evaluation of cheese prepared by processing camel milk. Pakistan J. Zool.36:323-326.

Kherouatou N, Moncef N,Attia H (2003). A study of the dromedary casein micelle and its changes during acidification.Brazil J. Food Technol. 6(2): 237-244.

Llorente BE,Brulti CB, Natalucci C L, Caffini y O (1997). Partial characterization of a milk clotting proteinase isolated from Artichoke (CynaraScolymusL., Asteraceae). ActaFarmaceuticaBonaerense 16 (1): 37-42.

Mariela AB, Lazza CM, Errasti ME, Lo' pez LMI, Caffini NO,Pardo MF(2010). Milk clotting and proteolytic activity of an enzyme preparation from Bromeliahieronymi fruits.LWT - Food Sci. Technol.43: 695-701.

Mehaia AM (1997). Studies on rennet coagulation of skim camel milk concentrated by ultrafiltration. J.KingSaud Univ. Agri. Sci. 9(1): 11 123.

Mehaia MA(2006). Manufacturing of fresh soft white cheese (Domaiti type) from dromedary milk using ultrafiltration process.J. Food Technol. (4)3: 206-212.

Mohammed O, Abdella M, Dawal A, Adam A, Mohamed BE(2010). Extraction milk clotting activity measurements and purification of SolanumdubiumFresen (Gubbain) for cheesemaking.World $\mathrm{J}$. Dairy Food Sci.5(2): 152-159.

Rodrigues AD, Bebora MRD, Keila AM, Maria LF, Jose'Lusi THC, Ana LAFP, (2009). JacaratiacorumbensisO. Kuntze a new vegetable source for milk-clotting enzymes. Brazilian Archive Biol. Technol.52 (1): 1-9.

Salvador A, Fiszman SM(2004).Textural and sensory characteristics of whole and skimmed flavoured set-type yoghurt during long storage.J. Dairy Sci.87(12): 4033-4041.

Sidrach L, Garci'a CF, Tudela J, Rodrıguez Lo'pez JN(2005). Purification of cynarases from Artichoke (CynarascolymusL.): Enzymatic properties of cynarase A. Phytochem. 66: 41-49.

Soledad C, Sidrach L, Lo'pez-Molin D, Rodrıguez-Lo'pez JN (2007).Characterization of the milk clotting properties of extracts from AAnimal Production and Health Paper Vol. 113.Artichoke (Cynarascolymus, L.) flowers.Int. Dairy J.17: 1393-1400.

How to cite this article: Hailu Y, Seifu E. and Yilma Z. (2014). Clotting activity of camel milk using crude extracts of ginger (Zingiber officinale) rhizome. Afr. J. Food Sci. Technol. 5(3):90-95 